\title{
Pemanfaatan Teknologi Augmented Reality Untuk Pengembangan Bahan Ajar Materi Komputer Jaringan
}

\author{
Listia Nuraini $^{1}$, Dwi Ratnawati ${ }^{2}$ \\ ${ }^{1,2}$ Universitas Teknologi Yogyakarta \\ ${ }^{1}$ nurainilistia@gmail.com*,2 dwiratnawati@uty.ac.id \\ * corresponding author
}

\begin{tabular}{|c|c|}
\hline ABSTRACT & Article Info \\
\hline $\begin{array}{l}\text { This study aims to develop Augmented Reality based learning media on computer } \\
\text { network subject. The research method used in developing educational games is } \\
\text { the research and development (R\&D) method adapted from Borg \& Gall. The } \\
\text { steps of study namely needs analysis, identification of product specifications, } \\
\text { product development, product validation, product revision and product testing. } \\
\text { The subject of this study was students of class X at Vocational High School. The } \\
\text { object of this study was Augmented Reality based learning media on computer } \\
\text { network. The test results indicated that this media is feasible to use. The score of } \\
\text { product validation gained } 73.07 \% \text { from media experts while it gained } 87.5 \% \\
\text { from material experts under very decent category. Moreover, it gained } 85,26 \% \\
\text { from product users under very feasible category. In addition, the effectiveness } \\
\text { test indicated that the result was quite effective with a percentage of } 64.41 \% \text {. } \\
\text { Therefore, it could be implied that this learning media was feasible and effective } \\
\text { to use in learning process. }\end{array}$ & $\begin{array}{r}\text { Article history } \\
\text { Received: Oct. } 18^{\text {th }}, 2021 \\
\text { Revised: Nov. } 25^{\text {th }}, 2021 \\
\text { Accepted: Nov. } 30^{\text {th }}, 2021\end{array}$ \\
\hline ABSTRAK & \\
\hline $\begin{array}{l}\text { Tujuan penelitian ini adalah pengembangan media pembelajaran berbasis } \\
\text { Augmented Reality pada mata pelajaran jaringan komputer. Metode penelitian } \\
\text { yang digunakan dalam mengembangkan game edukasi yaitu metode research } \\
\text { and development ( } R \& D \text { ) yang diadaptasi dari Borg \& Gall dengan beberapa } \\
\text { tahapan. Adapun langkahnya adalah analisis kebutuhan, identifikasi spesifikasi } \\
\text { produk, pengembangan produk, validasi produk, revisi produk dan uji coba } \\
\text { produk. Subjek penelitian ini adalah siswa kelas X SMK. Objek penelitian adalah } \\
\text { media pembelajaran jaringan komputer berbasis Augmented Reality. Hasil } \\
\text { ujicoba menyatakan bahwa media ini layak digunakan dengan prosentasi dari ahli } \\
\text { media sebesar } 73,07 \% \text {, ahli materi mendapat } 87,5 \% \text { dengan kategori sangat } \\
\text { layak, sedangkan pengguna mendapatkan } 85,26 \% \text { dengan kategori sangat layak. } \\
\text { Sedangkan uji efektivitas menyatakan cukup efektif dengan prosentase } 64,41 \% \text {, } \\
\text { sehingga disimpulkan bahwa media pembelajaran ini layak dan efektif digunakan } \\
\text { dalam pembelajaran. }\end{array}$ & \\
\hline
\end{tabular}

\section{PENDAHULUAN}

Pesatnya perkembangan teknologi mengalami kemajuan yang luar biasa, teknologi informasi mempunyai peranan yang sangat mendominasi pada masyarakat. Salah satu alat komunikasi yang sangat berkembang adalah handphone. Handphone adalah alat yang paling sering dipakai pada aktivitas sehari-hari. Menurut Assosiasi Penyelenggara Jasa Internet Indonesia data menunjukkan sebesar 73,7\% masyarakat Indonesia sudah menggunakan teknologi dan 96,6\% memakai aplikasi android (APPI: 2019). Sebagai contoh bidang yang menggunakan handphone adalah pendidikan. Pandemi covid 19 membuat pelaksanaan belajar 
wajib dilaksanakan secara online atau jarak jauh, sehingga menyebabkan guru harus mampu mensiasati pembelajaran agar menjadi menarik dan tidak monoton. Covid 19 berkembang di wuhan akhir 2019. Penularan virus ini tidak mudah dikendalikan sehingga semua orang terkena dampak Covid 19. Semua sektor lumpuh baik sektor ekonomi maupun pendidikan sehingga semua sekolah menerapkan SWH (School From Home) (Dwi \& Vivi, 2021: 110-118). SWH dilakukan supaya tidak terjadi penyebaran COVID-19. Sekitar 1,5 milyar siswa terdampak COVID-19, sehingga semua kegiatan pembelajaran dihentikan karena menimbulkan kerumunan (Purwanto dkk, 2020:1).

Pembelajaran Jarak Jauh merupakan belajar yang dilakukan tidak secara tatap muka dan tempat yang sama, pelaksanaan belajar jarak jauh dilakukan menggunakan bantuan media (Prawiyogi \&Anggy, 2020: 94-101). Pelaksanaan belajar daring menuntut siswa belajar mandiri dan terpisah dengan guru sehingga sumber belajarnya menggunakan media internet dan media online. Pendidikan jarak jauh mempunyai karakteristik 1) terpisahnya tenaga pendidik dan peserta didik dalam pelaksanaan pembalajaran, 2) terpisahnya seorang siswa dengan siswa lainnya selama pembelajaran, 3) terdapat instansi yang mengelola pelaksanaan pendidikannya. 4) memanfaatkan teknologi sebagai bahan belaja. (Sulistio, 2021: 63-69). Penggunaan teknologi memungkinkan guru dan siswa melaksanakan proses belajar mengajar walaupun ditempat yang berbeda (Firman \& Sari Rahayu, 2020: 81-89).

Mata pelajaran jaringan komputer merupakan salah satu mata pelajaran yang tidak mungkin dilakukan tanpa praktikum. Sebelum pandemi covid 19 pelajaran ini bisa dilaksanakan secara praktikum dikelas dengan modul dan peralatan yang sudah disediakan oleh sekolah. Terjadinya pandemi menyebabkan mata pelajaran ini tidak bisa dilakukan secara luring disekolah karena adanya peraturan lockdown, hal ini menyebabkan siswa tidak bisa melaksanakan praktikum secara mandiri. Ketidaksiapan siswa melakukan praktikum secara mandiri dikarenakan ketidakmampuan siswa dalam membeli peralatan jaringan yang harganya relatif mahal. Teknologi mobile mempunyai sumbangan yang besar di lembaga pendidikan terutama dalam pencapaian pelaksanan Pendidikan jarak jauh Sadikin, Ali, and Afreni Hamidah (2020: 214-224). Pengembangan media pembelajaran harus dilakukan oleh guru sesuai dengan kebutuhan mata pelajaran dan kebutuhan siswa. Sebagai contoh media pembelajaran yang mampu mengimbangi pelaksanaan pelaksanaan belajar praktikum secara daring adalah media belajar yang dikembangkan dengan teknologi Augmented Reality. Teknologi Augmented Reality dalam pengembangan media belajar bisa menampilkan objek secara nyata sehingga pengguna mampu berintereksi dengan lingkungan secara nyata Vivi \& Dwi (2021: 127-134). Hal ini dikemukan oleh Ardianti, Wanabuliandari, dan Raharjo (2021: 1-5) pembelajaran yang dilakukan dengan keterlibatan lingkungan dapat membantu peserta didik memperoleh pemahaman yang bermakna karena seolah-olah siswa melakukan pembelajaran secara langsung dan nyata. Dari berbagai masalah diatas maka peneliti bermaksud mengembangan media belajar menggunakan teknologi Augmented Reality pada mata pelajaran jaringan komputer.

\section{METODE}

Dalam penelitian dengan tema diatas metode yang digunakan adalah deskriptif kuantitatif. Metode deskriptif digunakan untuk menjabarkan dan analisis data hasil penelitian yang sudah kumpul tanpa adanya kesimpulan yang berlaku secara luas atau generalisasi (Sugiyono, 2013:147). Metode kuantitatif digunakan untuk pengujian berbagai macam teori dengan penelitian yang mencari hubungan antar variabel. Variabel yang diukur menggunakan instrumen penelitian, sehingga data yang diperoleh merupakan angka yang dapat dianalisis (Sugiyono 2013:148). Prosedur pengembangan yang diterapkan sebagai berikut: 


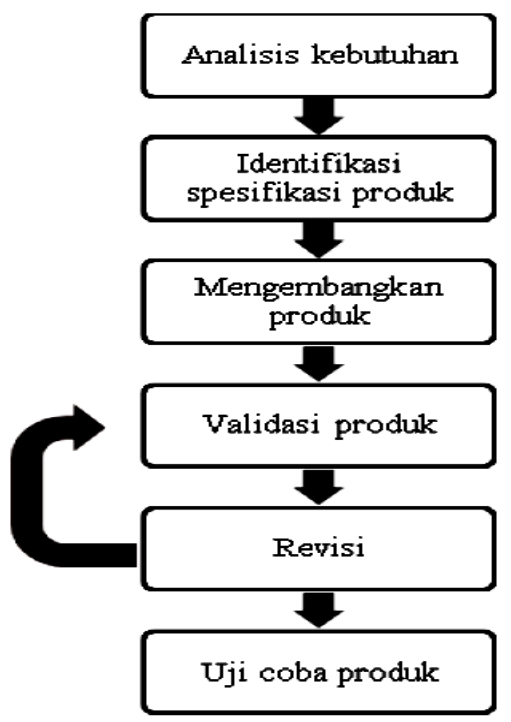

Gambar 1. Prosedur pengembangan

Berikut uraian untuk masing-masing tahap 1) Potensi dan masalah, tahapan ini meliputi kajian pustaka dan observasi. Kajian pustaka dilakukan dengan cara studi literasi untuk mendapatkan informasi mengenai penelitian. Observasi ditujukan untuk menggali informasi mengenai permasalahan pada anak dan diberikan solusi dalam aplikasi yang dibangun; 2) pengumpulan data dilakukan dengan wawancara kepada pendidik dan siswa. 3) Desain produk dilakukan dengan dalam bentuk perancangan storyboad; Pengembangan produk sesuai dengan storyboard yang sudah dibuat; 4) Validasi desain dilakukan untuk mengetahuai apakah desain tersebut sudah sesuai dengan produk yang akan dikembangkan. Validasi ini dilakukan dengan bantuan ahli materi dan ahlimedia; 5) Revisi dilakukan untuk memperbaiki masukan dari ahli media dan ahli materi; 6) Uji Coba Produk. Uji coba produk. Penelitian ini menggunakan subjek berjumlah 8 responden. Objek penelitian adalah media pembelajaran jaringan computer berbasis Augmented Reality. Kuesioner digunakan untuk pengumpulan data yang dinilai oleh ahli materi, ahli media dan peserta didik. Sedangkan pengukuran efektivitas produk dilakukan kepada peserta didik kelas X di SMK Negeri 1 Ketapang. Instrumen yang dipakai dapat dilihat pada tabel dibawah ini:

Tabel 1: Instrumen penelitian

\begin{tabular}{lll}
\hline & Aspek & Jumlah butir \\
\hline Ahli media & Tampilan & 13 \\
\hline \multirow{2}{*}{ Ahli materi } & Program & 6 \\
\hline & Kualitas materi & 4 \\
\hline & Kebermanfaatan & 2 \\
\hline Pengguna & Kesesuaian Bahasa materi & 2 \\
\hline & Materi & 4 \\
\hline
\end{tabular}

\section{HASIL DAN PEMBAHASAN}

Penelitian ini dimaksudkan untuk mengembangkan bahan ajar untuk pembelajaran menggunakan teknologi Augmented Reality pada mata pelajaran jaringan komputer, adapaun tahapannya adalah: 


\section{Analisis Kebutuhan}

Tahapan pertama adalah analisis kebutuhan dilakukan untuk mencari kajian Pustaka, Observasi dan identifikasi permasalahan terkait dengan pelaksanaan pembelajaran jaringan komputer. Tahapan dilaksanakan untuk menganalisis kebutuhan apa saja dari produk yang akan dikembangkan baik kebutuhan software maupun hardware.

\section{Identifikasi Spesifikasi Produk}

Tahapan ini digunakan untuk melakukan penyusunan storyboard. Storyboard adalah gambar sketsa yang diwujudkan dalam bentuk panel. Sketsa ini dibuat secara berurutan hingga membentuk alur cerita yang dikembangkan (Lestari, Agustini, dan Sugihartini 2019). Berikut ini merupakan story board aplikasinya.

Tabel 2. Storyboard

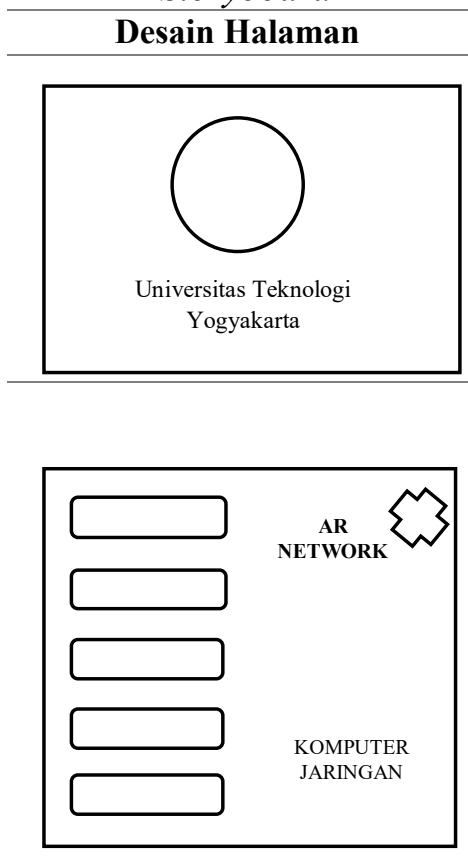

A. Halaman in adalah halaman awal pada saat membuka aplikasi.

B. Terdapat logo UTY

A. Halaman ini adalah halaman menu utama

B. Memiliki tombol:

1. Tombol exit

2. Tombol AR SCAN

3. Tombol KI \& KD

4. Tombol Petunjuk

5. Tombol kuis

6. Tombol Info pengembang

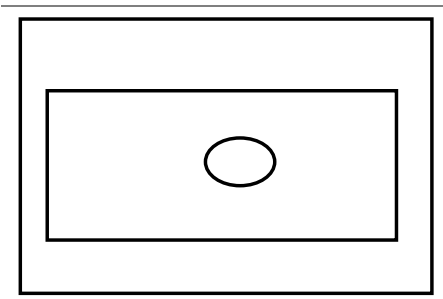

A. Halaman ini adalah halaman kuis

B. Memiliki tombol:

1. Tombol Mulai

2. Tombol Kembali

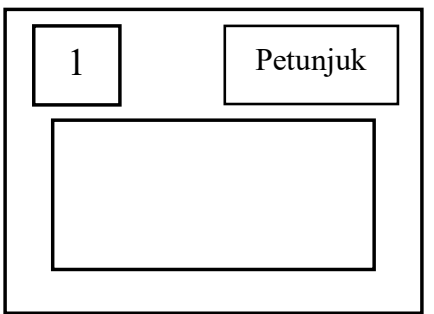

A. Halaman ini adalah halaman petunjuk

B. Memiliki tombol:

Tombol Kembali

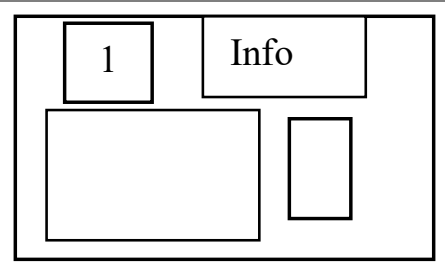

A. Halaman ini adalah halaman Info pengembang

B. Memiliki tombol:

Tombol Kembali
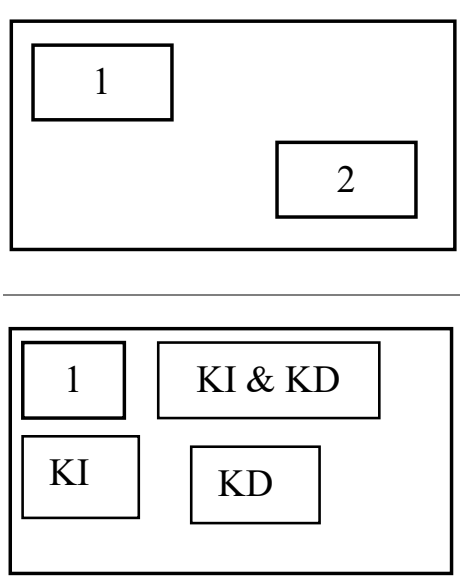

A. Halaman ini adalah halaman KI \& KD

B. Memiliki tombol: Tombol Kembali

\section{Pengembangan Produk}

Produk utama dari sistem ini yaitu sebuah mengembangkan bahan ajar untuk pembelajaran menggunakan teknologi Augmented Reality. Media belajar ini terdiri atas beberapa menu utama yaitu sebagai berikut.

a. Tampilan awal dari aplikasi media pembelajaran Augmented Reality materi komputer jaringan ini muncul setelah aplikasi dijalankan. Tampilan awal dari aplikasi media pembelajaran Augmented Reality materi komputer jaringan seperti gambar 2

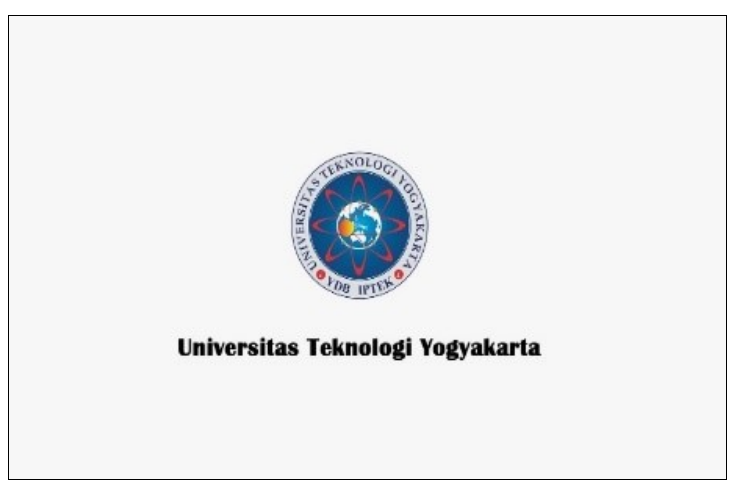

Gambar 2. Tampilan awal 
b. Tampilan awal dari aplikasi media pembelajaran Augmented Reality materi komputer jaringan akan tampil sesudah proses loading. Tampilan utama pada program ini adalah menu petunjuk, KI \& KD, Materi, Ar Scan, Kuis, Referensi, Info Pengembang, tombol petunjuk, dan tombol keluar. Untuk tampilan utama dari aplikasi media pembelajaran Augmented Reality materi komputer jaringan seperti pada gambar 3.

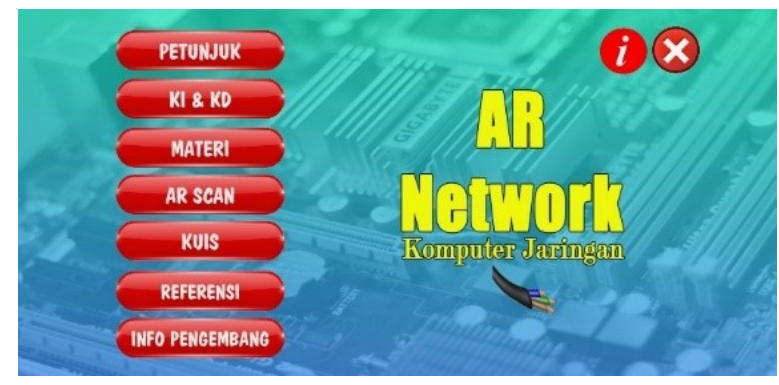

Gambar 3. Tampilan utama

c. Selanutnya adalah petunjuk, petunjuk dari aplikasi media pembelajaran Augmented Reality materi komputer jaringan muncul setelah klik petunjuk. Petunjul berisi tentang petunjuk-petunjuk dalam pemakaian aplikasi. Tampilannya pada aplikasi media pembelajaran Augmented Reality materi komputer jaringan bisa dilihat pada gambar 4.

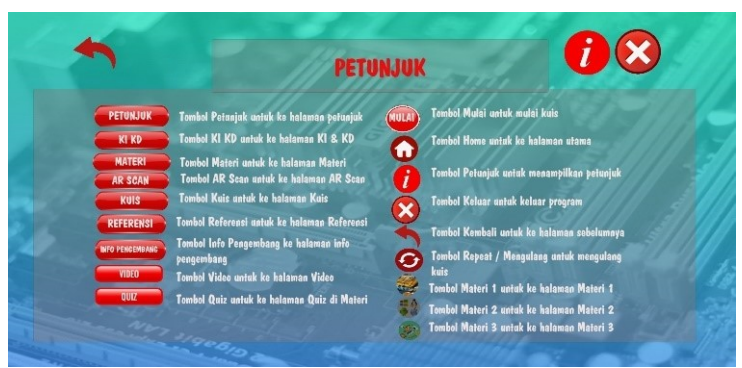

Gambar 4. Tampilan petunjuk

d. Tampilan KI KD dari aplikasi belajar Augmented Reality materi komputer jaringan ini tampil saat tombol KI KD diklik. Pada tampilan KI KD ini berisi informasi terkait KI KD pada mata pelajaran jaringan dasar. Tampilan KI KD dari aplikasi media pembelajaran Augmented Reality materi komputer jaringan ini seperti pada gambar 5 .

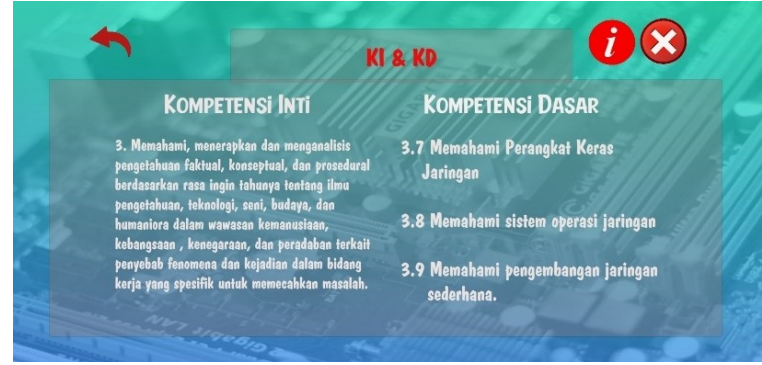

Gambar 5. Tampilan KI KD

e. Tampilan kuis dari aplikasi media pembelajaran Augmented Reality materi komputer jaringan tampil saat tombol kuis diklik. Tampilan kuis akan berisi soal pilihan ganda. Tampilan kuis dari aplikasi media pembelajaran Augmented Reality materi komputer jaringan seperti pada gambar 6 .

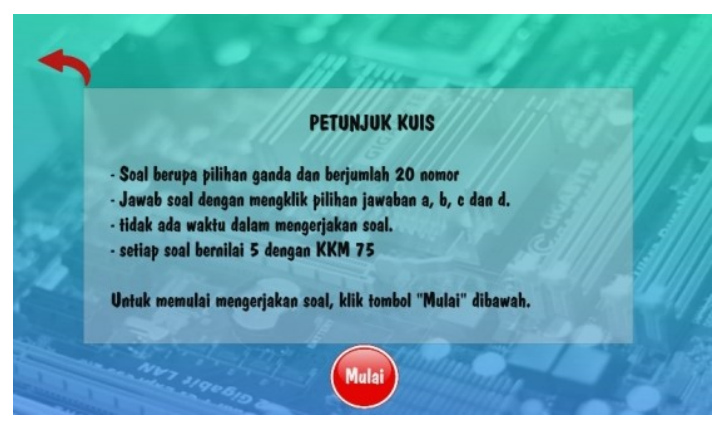

Gambar 6. Tampilan kuis

f. Tampilan materi dari aplikasi media pembelajaran Augmented Reality materi komputer jaringan akan tampil setelah klik tombol materi. Link materi ini berisi materi penjelasan peralatan jaringan, sistem operasi jaringan, dan pengembangan jaringan sederhana. Tampilan materi dari aplikasi media pembelajaran Augmented Reality materi komputer jaringan ini seperti pada gambar 7.

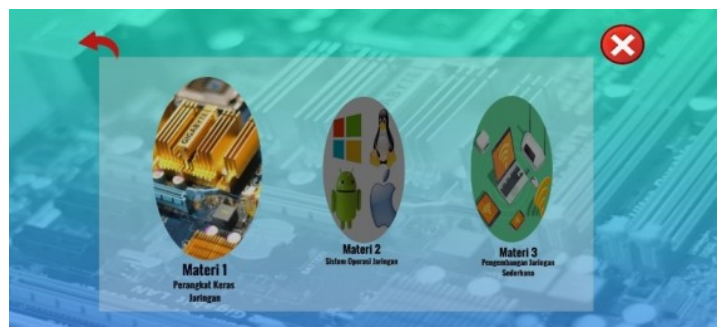

Gambar 7. Tampilan materi 
g. Tampilan AR Scan dari aplikasi media pembelajaran Augmented Reality materi komputer jaringan akan tampil setelah klik tombol AR Scan. Tampilan AR Scan berisikan petunjuk penggunaan AR Scan dan ketika diklik mulai akan menuju ke tampilan scan marker. Tampilan AR Scan dari aplikasi media pembelajaran Augmented Reality materi komputer jaringan seperti dilihat pada gambar 8 .

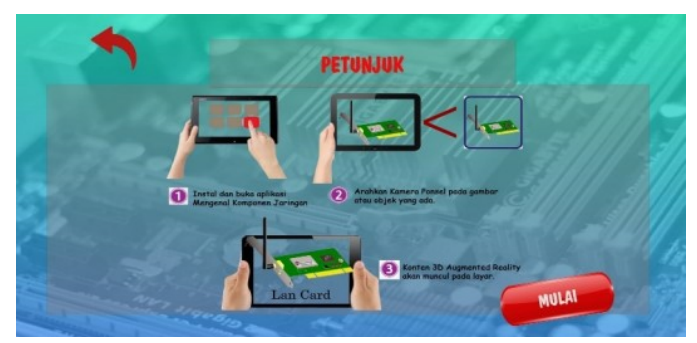

Gambar 8. Tampilan AR

h. Tampilan Referensi dari aplikasi media pembelajaran Augmented Reality materi komputer jaringan akan tampil setelah klik tombol referensi. Tampilan referensi berisi referensi materi komputer jaringan. Tampilan referensi dari aplikasi media pembelajaran Augmented Reality materi komputer jaringan seperti pada gambar 9 .

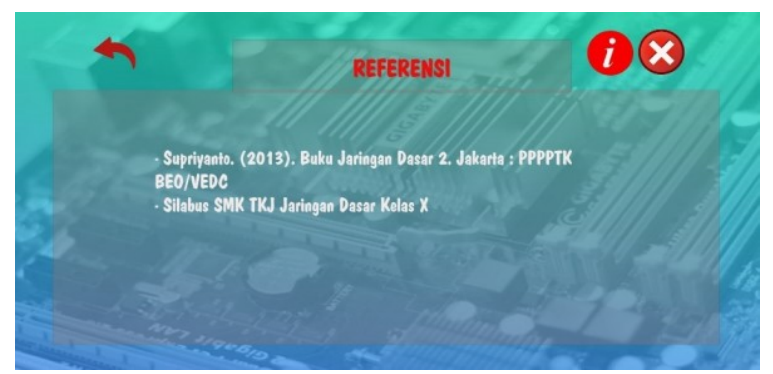

Gambar 9. Tampilan Referensi

i. Pada tampilan info pengembang dari aplikasi media pembelajaran Augmented Reality materi komputer jaringan akan tampil setelah klik tombol Info pengembang. Tampilan info pengembang berisikan info pengembang. Tampilan info pengembang dari aplikasi media pembelajaran Augmented Reality materi komputer jaringan ini dapat seperti pada gambar 10 .

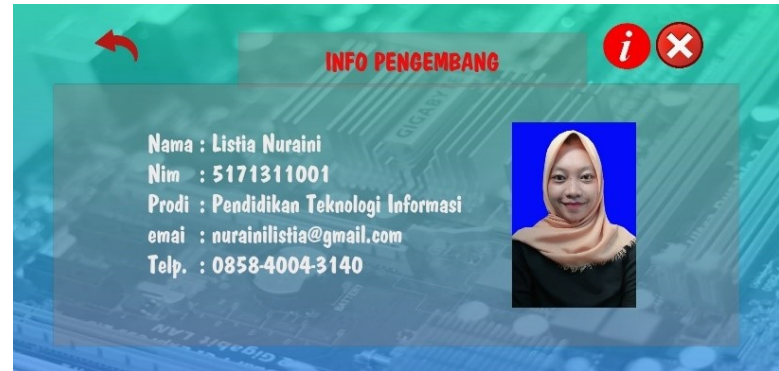

Gambar 10. Tampilan info pengembang

\section{Validasi Produk}

Pelaksanaan validasi oleh dua ahli yaitu ahli media dan ahli materi. Validasi menunjukkan ada revisi yaitu pada penggunaan warna background dan bentuk tulisan.

\section{Revisi}

Revisi dilakukan untuk melakukan perbaikan sesuai arahan dari ahli materi dan media. Maka peneliti melakukan penggantian warna pada bagian background.

\section{Uji Coba Produk Terbatas}

Ujicoba dilakukan dengan ujicoba lapangan skala kecil yaitu pada 8 responden, peneliti membagian kuesioner yang berjumlah 7 butir pertanyaan. Pertanyaan ini meliputi 4 butir untuk aspek media dan 3 butir untuk aspek materi. Respon masing-masing pernyataan terwujud dalam bobot berupa angka 1 hingga 4 . Selanjutnya, bobot pada masing-masing aspek dijumlahkan dan dilakukan perhitungan persentase skor. Nilai persentase yang diperoleh kemudian dikonversi menjadi tingkat kelayakan seperti pada tabel (Arikunto 2006).

Tabel 3. Konversi kelayakan

\begin{tabular}{ll}
\multicolumn{1}{c}{$\begin{array}{c}\text { Konversi } \\
\text { Kelayakan }\end{array}$} & \multicolumn{1}{c}{$\begin{array}{c}\text { Persentase Pencapaian } \\
\text { Interpretasi }\end{array}$} \\
\hline $76-100 \%$ & Sangat Layak \\
\hline $41-55 \%$ & Cukup \\
\hline $56-75 \%$ & Layak \\
\hline $0-40 \%$ & Kurang Layak \\
\hline
\end{tabular}

Hasil ujicoba yang dilakukan ahli media pada aspek tampilan medapatkan $78,85 \%$, aspek program mendapatkan 79,16\%. Berdasarkan skor dari tampilan dan program tersebut didapatkan skor kelayakan media 73,07\%, sehinggan dikategorikan pada kategori layak. 


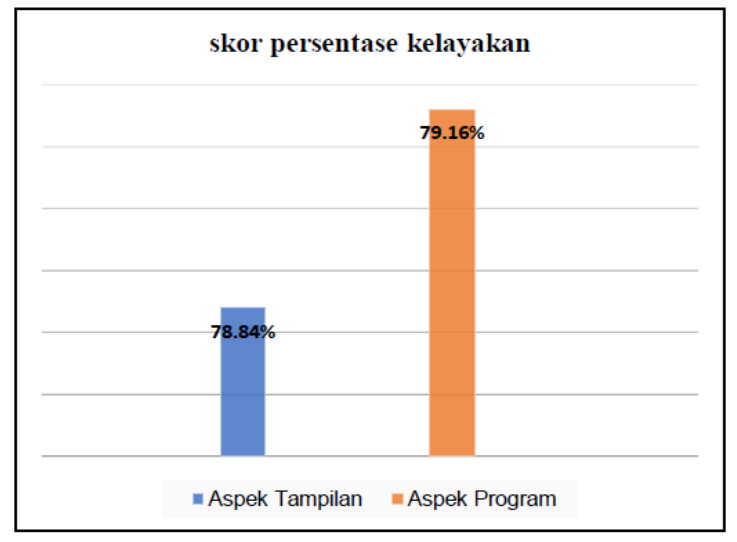

Gambar 11. Skor kelayakan ahli media

Ujicoba yang dilaksanakan ahli materi pada aspek materi medapatkan $93,75 \%$, aspek kebermanfaatan mendapatkan $75 \%$, aspek kesesuaian Bahasa materi mendapat 87,50\%. Berdasarkan skor dari kedua aspek didapatkan nilai sebesar $87,5 \%$ sehingga masuk dalam kategori sangat layak.

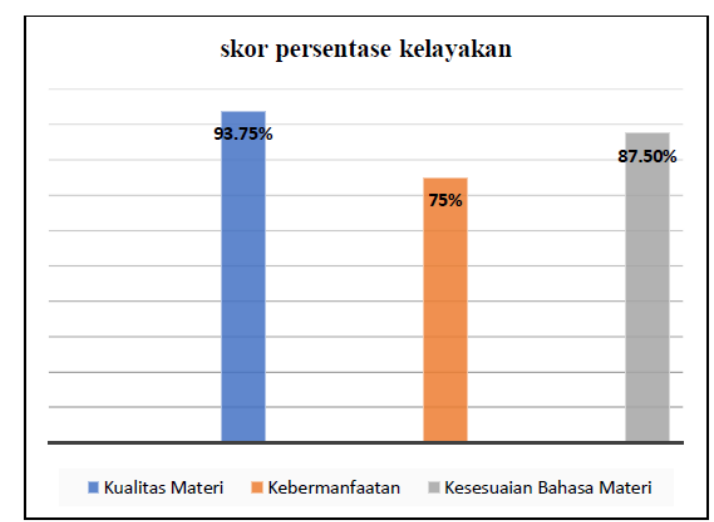

Gambar 12. Skor kelayakan ahli materi

Hasil ujicoba yang dilakukan pengguna pada aspek materi medapatkan $84,37 \%$, aspek media mendapatkan 86,46\%. Berdasarkan ketiga aspek maka diperoleh nilai kelayakan dari media sebesar $85,26 \%$ sehingga masuk pada kategori sangat layak.

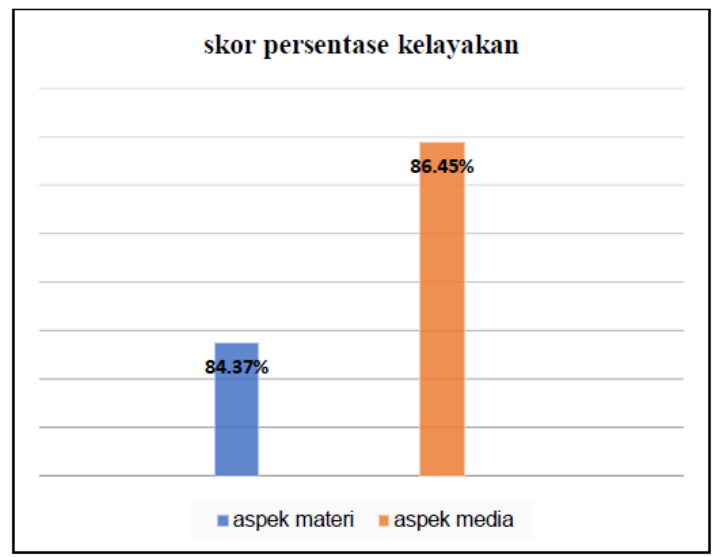

Gambar 13. Skor pengguna

Dari hasil uji ahli materi, media dan pengguna diatas maka disimpulkan aplikasi layak dipakai pada pelaksanaan belajar.

Selanjutkan pengujian yang dilakukan adalah mencari efektivitas penggunaan program dalam pelaksanaan pembelajaran. Pengujian efektivitas ini dilakukan kepada peserta didik kelas X di SMK Negeri 1 Ketapang. Pengujian efektivitas digunakan agar bisa mengetahui adanya pengaruh bahan agar berteknologi Augmented Reality materi komputer jaringan pada hasil pembelajaran siswa kelas X SMK N1 Ketapang Lampung Selatan. Pengujian efektivitas menerapkan rumus N-Gain Score yaitu untuk membandingkan hasil belajar sebelum memakai media (pretest) dan hasil belajar setelah memakai media (posttest). Hasilnya digunakan untuk penarikan kesimpulan. Setelah mendapatkan hasil dari pretest dan posttest dilanjutkan dengan pengujian untuk mengetahui ada tidaknya perbedaan kemampuan belajar peserta didik dengan menggunakan media. Hasil penggujian yang didapatkan dapat dilihat dibawah ini: 
Tabel 4. Hasil pengujian

\begin{tabular}{|c|c|}
\hline No. & N-Gain Score $(\%)$ \\
\hline 1 & 42.86 \\
\hline 2 & 60.00 \\
\hline 3 & 50.00 \\
\hline 4 & 77.78 \\
\hline 5 & 33.33 \\
\hline 6 & 77.78 \\
\hline 7 & 80.00 \\
\hline 8 & 83.33 \\
\hline 9 & 80.00 \\
\hline 10 & 88.89 \\
\hline 11 & 61.54 \\
\hline 12 & 76.92 \\
\hline 13 & 75.00 \\
\hline 14 & 77.78 \\
\hline 15 & 40.00 \\
\hline 16 & 28.57 \\
\hline 17 & 72.73 \\
\hline 18 & 85.71 \\
\hline 19 & 77.78 \\
\hline 20 & 0.00 \\
\hline 21 & 60.00 \\
\hline 22 & 50.00 \\
\hline 23 & 90.00 \\
\hline 24 & 33.33 \\
\hline 25 & 88.89 \\
\hline 26 & 50.00 \\
\hline 27 & 33.33 \\
\hline 28 & 71.43 \\
\hline 29 & 71.43 \\
\hline 30 & 85.71 \\
\hline 31 & 71.43 \\
\hline 32 & 57.14 \\
\hline
\end{tabular}

\begin{tabular}{cc}
\hline 33 & 64.29 \\
\hline 34 & 92.86 \\
\hline Rata-rata & 64.41 \\
\hline Minimal & 0.00 \\
\hline Maksimal & 92.86
\end{tabular}

Hasil pengujian menggunakan SPP adalah sebagai berikut:

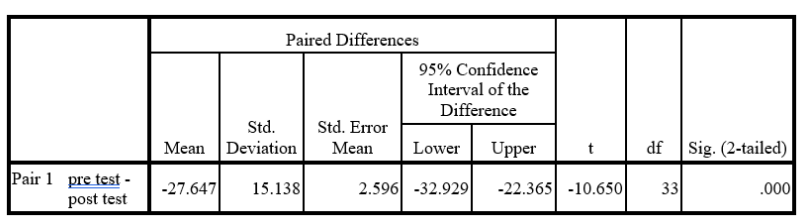

Gambar 14. Paired Samples Test

Menurut Santosa (2014), panduan dalam mengambil sebuah keputusan pada uji paired sample t-test didasarkan pada nilai signifikansi (Sig.) menggunakan output SPSS, hasilnya adalah seperti dibawah ini.

1. Nilai Sig. (2-tailed) $<0,05$, maka HO ditolak dan Ha diterima.

2. Nilai Sig. (2-tailed) $>0,05$, maka $\mathrm{HO}$ diterima dan Ha ditolak.

Gambar diatas merupakan output "Paired Samples Test", dengan nilai Sig. (2-tailed) sebesar $0,002<0,05$, sehingga HO ditolak, Ha diterima. Maka disimpulkan adanya perbedaan rerata hasil belajar pretest dengan posttest, sehingga dapat disimpulkan adanya pengaruh media belajar Augmented Reality materi komputer jaringan.

Gambar keluaran "Paired Samples Test" menunjukkan hasil skor "Mean Paired Differences" dengan nilai -27,647. Skor ini memperlihatkan adanya selisih antara rerata hasil belajar pretest dengan rerata hasil belajar posttest dengan nilai $60,15-87,79=-27,647$ sehingga muncul selisih beda antara $-32,929$ sampai -22,365 (95\% Confidence Interval of the Difference Lower dan Upper).

Gambar output "Paired Samples Test" di atas, dapat dilihat $t$ hitung bernilai negatif yaitu sebesar -10,650. $\mathrm{t}$ hitung bernilai negatif ini dikarenakan nilai rerata hasil belajar pretest 
lebih rendah dibandingkan rerata hasil belajar posttest. Maka $\mathrm{t}$ hitung yang negative bisa diartikan positif karena $t$ hitung menjadi 10,650 .

Tahap selanjutnya adalah mencari nilai $\mathrm{t}$ tabel, $\mathrm{t}$ tabel akan dilakukan pencarian didasarkan pada nilai df (degree of freedom atau derajat kebebasan) dan nilai signifikansi (a/2). Hasil nilai df sebesar 33 sedangkan nilai $0,05 / 2$ sama dengan 0,025 , sehingga $t$ tabel yang diperoleh sebesar 2.03452 .

Dikarenakan nilai $\mathrm{t}$ hitung $10,650>\mathrm{t}$ tabel 2.03452, sehingga dapat disimpulkan HO ditolak dan Ha diterima. Maka kesimpulan yang dapat diambil adalah ada perbedaan rerata antara hasil belajar pretest dengan posttest sehingga dapat diartikan adanya pengaruh penggunaan media pembelajaran Augmented Reality materi komputer jaringan dalam meningkatkan hasil belajar.

\section{SIMPULAN}

Berdasarkan penelian yang sudah dilakukan dapat disimpulkan (1) penelitian ini menghasilkan produk bahan ajar dengan teknologi Augmented Reality untuk mata pelajaran jaringan di SMK, (2) bahan ajar berupa produk dinilai dalam kategori sangat layak, sehingga bisa digunakan dalam pembelajaran, (3) efektivitas media termasuk kategori cukup efektif sehingga dalam membantu guru dalam melaksanakan pembelajaran pada mata kuliah jaringan komputer

\section{DAFTAR RUJUKAN}

Ardianti, Sekar Dwi, and Savitri Wanabuliandari, 2021 EthnoEdutainment Digital Module to Increase Students' Concept Understanding. Journal of Physics: Conference Series. Vol. 1823. No. 1. IOP Publishing, 1-5

Asosiasi Penyelenggara Jasa Internet Indonesia [APJII]. 2019. Profil Pengguna Internet
Indonesia. Jakarta: Asosias Penyelenggara Jasa Internet Indonesia

Firman, Firman, and Sari Rahayu, 2020. Pembelajaran online di tengah pandemi covid-19. Indonesian Journal of Educational Science (IJES). 2.2, 81-89.

Lestari, K. D., Agustini, K., dan Sugihartini, N.2019. Pengembangan Modul Ajar Storyboard Berbasis Projeck Based Learning untuk Siswa Kelas XI Multimedia di SMK TI Bali Global Singaraja. Karmapati. 8 (2), 309-318.

Prawiyogi, Anggy Giri, et al. 2020. Efektivitas Pembelajaran Jarak Jauh Terhadap Pembelajaran Siswa di SDIT Cendekia Purwakarta. Jurnal Pendidikan Dasar. 11.1, 94-101.

Ratnawati, Dwi, and Vivianti Vivianti. 2020. Persepsi Mahasiswa Terhadap Pembelajaran Daring Pada Mata Kuliah Praktik Aplikasi Teknologi Informasi. Jurnal Edukasi Elektro. 4.2, 110-119.

Sadikin, Ali, and Afreni Hamidah. 2020. Pembelajaran Daring Di Tengah Wabah Covid-19 (Online Learning in the Middle of the Covid-19 Pandemic). Biodik. 6.2, 214-224.

Santosa, S. 2014. Panduan Lengkap SPSS. Jakarta: PT. Elex Media Komputindo.

Sugiyono. 2013. Metode Penelitian Kuantitatif, Kualitatif dan $R \& D$. Bandung: Alfabeta.CV

Sulistio, Andi. 2021. Peningkatan Prestasi Belajar Bahasa Inggris Melalui Pembelajaran Jarak Jauh (PJJ) Dalam Penerapan Pembelajaran Sinkron Dan Asinkron Melalui Google Classroom, Google Meet Dan Aplikasi E-Learning. Secondary: Jurnal Inovasi Pendidikan Menengah. 1.2, 63-69.

Vivianti, and Dwi Ratnawati. 2021. GAME EDUKASI MOBILE "AKU SUKA SAYUR" BERBASIS AUGMENTED REALITY UNTUK ANAK USIA DINI. Refleksi Edukatika: Jurnal Ilmiah Kependidikan. 11.2, 127-134. 